\title{
Causative Pathogen of Fire Blight of Fruit Trees in Georgia
}

\author{
Amashukeli Nanuli, Gaganidze Dali, \\ Aznarashvili Mariam, Kharadze Shorena, \\ Sturua Neli, Sadunish vili Tinatin \\ Sergi Durmishidze Institute of Biochemistry and Biotechnology, \\ Agricultural University of Georgia, 240, \\ David Aghmashenebeli Ave, Tbilisi, 0131 Georgia \\ https://doi.org/10.52340/idw.2021.488
}

\begin{abstract}
Fire blight is a devastating disease of fruit trees that first appeared in Georgia in 2016. Above 40 samples - fruit trees twigs, buds, flowers and fruitlets, suspected on the fire blight disease were collected in the Mtskheta-Mtianeti and Shida Kartli Regions, eastern Georgia in Summer of 2020. Based on visual observation and immunological test (Ea AgriStrip), 20 plant samples were selected for further study. PCR analysis was performed to detect pathogen in these samples with primers pair A: 5'-CGG TTT TTA ACG CTG GG-3' and B: 5'-GGG CAA ATA CTC GGA TT-3 ' and 2XPCR BIOTAG Mix using PCR BIOSYSTEMS. The pathogen Erwinia amylovora was detected in 6 samples: N10 and N11 apple samples (Ksovrisi); N12 apple sample (Kekhijvari); N14 apple sample (Karaleti); N16- apple sample (Tirdznisi); N27 pear sample (Osiauri). King's B, NSA and CCT media were used for the isolation of the pathogen from PCR-confirmed diseased samples serial dilutions. For the identification of Erwinia amylovora, PCR was performed in $25 \mu l$ reaction mixture with primers pair G1-F: 5'-CCT GCA TAA ATC ACC GCT GACAGC TCA ATG 3' and G2-R: 5GCT ACC ACT GAT CGC TCG AATCAA ATC GGC3'. The presence of E. amylovora was confirmed in the following isolates, \#\# 1012, 1022, 1023, 1131, 1133, 1212, 1412, 1612, 1742, and 2763. Study of the physiological-biochemical properties of the E. amylovora Georgian isolates revealed a little difference in the sugars utilization and the esculin hydrolysis abilities.
\end{abstract}

Keywords: Fire blight of fruit trees, Erwinia amylovora, PCR

Phytopathogenic bacteria affect a wide range of crops worldwide. Erwinia amylovora is a pathogen, causative of a fire blight disease, distinguished by its harmfulness. It damages various cultural and wild plants of the fruit trees, in particular 180 cultural and wild plants belonging to the Rosaceae family (Pulawska and Sobiczewski P. 2012). Aple, pear and quince are the most susceptible to the disease (OEPP/EPPO Bulletin, 2013).

The fire blight disease causes enormous economic losses around the world and poses threat of eradication to entire fruit tree garden. In 1971-1972, during the fire blight initial wave, 18000 plants of thornapple and pears were destructed in Germany, and $10 \mathrm{~km}$ thornapple hedges and about 175000 bushes - in Holland (Van der Zwet and Keil 1979).

Erwinia amylovora is included in the European and Mediterranean Plant Protection organization (EPPO) A2 list of quarantine organisms (EPPO 2007). It is also registered in the list of quarantine organisms of Australia (AQIS 1998) and South Africa. Since 2010 E.amylovora is included in list of quarantine organisms in Georgia.

The fire blight disease was first observed in New York State in 1780, detected in New Zealand in 1910, in UK in 1958 and then spread progressively accross Europe and Asia (Van der Zwet, 1996). The fire blight disease occurs now in almost 60 countries (https://gd.eppo.int/taxon/ERWIAM/distribution). Its spread in the temperate zones of the world 
appears to be unavoidable (Paulin 1997).

While long range spread is mainly due to trade of plant material the local source of dispersal is transmission of bacteria through milky exudates (ooze) from the damaged tissues of the plant by rain, wind, insects, birds and agricultural practices (infected tools, vehicles, fruits, etc.) (Beer and Norelli, 1977; Pusey 2002). The most infections take place through the flowers. High air humidity and temperature promote its proliferation and distribution (Billing, 2000).

The difficulty of fire blight control is conditioned by the lack of registered specific preparations effecting directly on pathogen. Spraying of the antibiotic streptomycin and the use of copper-containing preparations are the most effective control procedures, but not allowed in most countries, including Georgia, due to the fear of the emergence of resistances (Mc Ghee and Sundin, 2011). Among the current complex range of the disease control is the removal of the very first symptoms as soon as they appear, which reduces drastically subsequent infection (Paulin, 1997).

In 2016, the employees of the Diagnostics Department of Plant Harmful Organisms, Laboratory of the Ministry of Agriculture identified Erwinia amylovora in apple seedlings from Mtskheta district, village Ksovrisi (Kartli). In 2018 E. amylovora was confirmed in symptomatic fruit trees samples in Shida Kartli, Kvemo Kartli and Imereti regions in Georgia by Real time PCR (Gaganidze et al., 2018). The disease distribution among the regions of Georgia and genetic characterization of some E.amylovora isolates was also reported (Gaganidze et al., 2021).

The spread of the disease in eastern and western Georgia, posing a great challenge for the country's economy since pomiculture is one of the oldest and important fields of its agriculture

The goal of the paper is to isolate and study of the fire blight causative pathogen from affected fruit trees in eastern Georgia.

\section{Materials and methods}

\section{Sample collection}

Collection of samples has been conducted in 2020 in the orchards of different regions of Eastern Georgia. Mtskheta-Mtianeti region: Mtskheta district, villages Ksovrisi and Mukhrani; Shida Kartli region: Gori district, villages - Karaleti, Pkhvenisi and Tidznisi; Kareli district, village Kekhijvari, Khashuri district villages Osiauri and Gomi. Twigs, buds, flowers and fruitlets (with necrosis and exudates) from the plants, suspected on the fire blight disease were collected in the orchards of the above presented locations, where they were found. For the initial detection of the E.amylovora in the collected material, immunological fast test was conducted (AgriStrip Complete kit "BIoreba"). Positive and suspected samples were transferred to the laboratory as soon as possible.

\section{DNA extraction protocol}

DNA isolation has been carried out from collected plant samples. One gram of the tissue from the above stated samples were taken from the region between the diseased and healthy tissue and homogenized in $50 \mathrm{ml} 1 \mathrm{XPBS}$ buffer. The macerate was centrifuged at 10,000g for $5 \mathrm{~min}$ and the pellet was resuspended in $500 \mu \mathrm{l}$ of Tris- $\mathrm{HCl}$ buffer, $\mathrm{pH} 7.5$, containing $24.2 \mathrm{~g} \mathrm{NaCl}, 14.6 \mathrm{~g}$ EDTA, $9.3 \mathrm{~g}$ SDS, $5 \mathrm{~g}$ PVP10 per liter. After $1 \mathrm{~h}$ incubation at room temperature, the suspension was centrifuged at 4,000g for $5 \mathrm{~min}$. DNA was precipitated by adding of equal volume of isopropanol and centrifuged at $10,000 \mathrm{~g}$ for $15 \mathrm{~min}$. The pallet was washed with $70 \%$ ethanol twice and then suspended in $100 \mu 1 \mathrm{TE}$ (Tris-EDTA buffer, Merck).

\section{Detection of E. amylovora in plants}

Detection of E.amylowora was carried out by conventional PCR based on amplification of targeted sequence of the plasmid pEA29, which plays important role in plant-pathogen interaction. Primer pair: A (5'-CGG TTT TTA ACG CTG GG-3') and B ( 5'-GGG CAA ATA CTC GGA TT- 
3)' were applied in PCR reaction (Bereswill et al., 1992). Predicted PCR product is 900-1100 bp.

DNA extracted from the symptomatic plant twigs, buds, flowers and fruitlets was used as a matrix in PCR analysis. DNA isolation was performed by a method modified by us using the kit (GC proba, Agrodiagnostika). $50 \mathrm{ml}$ of 1XPBS buffer (1:50) was added to 1 gram of plant tissue (sampled from the boundary of damaged and healthy tissue) and incubated on a shaker at $25^{\circ} \mathrm{C}$ for 1 hour; the macerate was centrifuged at $14,000 \mathrm{~g}$ for 5 minutes. The resulting precipitate was dissolved in a $50 \mu \mathrm{l}$ XPBS buffer, added $170 \mu \mathrm{l}$ sorbent containing lysis buffer of the kit and incubated at $55^{\circ} \mathrm{C}$ for 20 minutes. The elution buffer of the kit was used for DNA elution.

PCR mixture in a total volume of $25 \mu \mathrm{l}$ contained $12.5 \mu \mathrm{l}$ XPCR BIO Tag Mix, PCR BIOSYSTEMS, Primers A and B at final concentration $0.1 \mu \mathrm{M}$ each and $2 \mu \mathrm{l}$ DNA. Positive controls contained DNA of E.amylovora reference strains NCPPB \#683 (National Collection of Plant Pathogenic Bacteria, Central Science Laboratory, York, UK). Negative control contained PCR grade water instead of DNA. PCR reaction was conducted in thermocycler TECHNE, TC 3000. Cycling conditions were: initial denaturation at $93^{\circ} \mathrm{C}$ for $5 \mathrm{~min}$, followed by 40 cycles of $93^{\circ} \mathrm{C}$ for $30 \mathrm{~s}, 52^{\circ} \mathrm{C}$ for $30 \mathrm{~s}$ and $72^{\circ} \mathrm{C}$ for $1 \mathrm{~min} 15 \mathrm{~s}$, with a final elongation step at $72^{\circ} \mathrm{C}$ for $10 \mathrm{~min}$.

Isolation and purification of E. amylowora

Plant samples, in which the fire blight causative bacteria E. amylovara were detected were washed with water and surface disinfected by soaking in $70 \%$ etanol for $3 \mathrm{~min}$, rinsed three times in sterile distilled water and gently dried with sterilized tissue paper. Small pieces of plant tissues were macerated in $1 \mathrm{ml}$ of sterile phosphate buffer saline (PBS) during $30 \mathrm{~min}$. After $30 \mathrm{~min}$ incubation at $25^{0} \mathrm{C} 10^{-1}, 10^{-2}$ and $10^{-3}$ dilutions were prepared. One drop $(30 \mu \mathrm{l})$ of macerate were and streaked onto three different media in Petri plates King's B (King et al., 1954), NSA (Nutrient Sucrose Agar) (Billing et al., 1961) and CCT (Crystal violet-cycloheximide-tergitol) agar medium (Ishimaru \& Klos, 1984) as is recommended for maximum recovery of E.amylovora. The plates were incubated at $25^{\circ} \mathrm{C}$ for $48-72 \mathrm{~h}$. After development of the bacteria colonies suspecious ones were purified on none selective King's B medium. For long-term storage cultures in $30 \%$ glycerol were placed in low-temperature freezer at $-80^{\circ} \mathrm{C}$.

Molecular identification of E. amylovora isolates

Molecular identification of Erwinia amylovora was conducted by PCR based on amplification of sequence near termini of the chromosomal pEA71 insert region with a synthesis of a $187 \mathrm{bp}$ PCR product as expected from the nucleotide sequence (Taylor et al., 2001). With this aim the specific primer pair: G1-F: 5'-CCT GCA TAA ATC ACC GCT GAC AGC TCA ATG-3' and G2R: 5'GCT ACC ACT GAT CGC TCG AAT CAA ATC GGC-3' was used to amplify DNA.

DNA was extracted from the isolates by the boiling. The 24-hour culture grown on solid medium was transferred to a $100 \mu \mathrm{l}$ TE buffer (Tris-EDTA, pH 7.4) with a sterile loop, incubated at $100{ }^{\circ} \mathrm{C}$ for 10 minutes, then cooled at $4{ }^{\circ} \mathrm{C}$ for 10 minutes and centrifuged $2 \mathrm{~min}$ at $3000 \mathrm{rpm}$. A supernatant containing DNA was used for the PCR reaction.

PCR mixture in a total volume of $25 \mu \mathrm{l}$ contained $12.5 \mu \mathrm{l}$ XPCR BIO Tag Mix, PCRBIOSYSTEMS, Primers G1 and G2 at final concentration $0.2 \mu \mathrm{M}$ each and $2 \mu \mathrm{l}$ DNA extracted from the isolates. Positive controls contained DNA of E.amylovora NCPPB \#683, Negative control contained PCR grade water instead of DNA.

PCR reaction was conducted in thermocycler TECHNE, TC 3000. Cycling conditions were: initial denaturation at $95^{\circ} \mathrm{C}$ for $3 \mathrm{~min}$, followed by 40 cycles of $94^{\circ} \mathrm{C}$ for $30 \mathrm{~s}, 60^{\circ} \mathrm{C}$ for $30 \mathrm{~s}$ and $72^{\circ} \mathrm{C}$ for $1 \mathrm{~min}$, with a final extention step at $72^{\circ} \mathrm{C}$ for $5 \mathrm{~min}$ and cooling at $8^{\circ} \mathrm{C}$.

Electrophoresis of PCR products was conducted on 1\% agarose gel in TAE buffer during 40 min at $80 \mathrm{~V}$. Staining was carried out with ethidium bromide and viewed by UV Transilluminator (Sambrook et al., 2000).

Phenotypic identification of E. amylovora isolates

For morphological identification of the suspected isolates pure cultures King's B (King et al., 
1954), CCT agar and NSA were used. Observation of colony morphology, such as size and shape was carried out by stereoscopic microscope (Leica M50). Bacterial cells were studied by light microscope (Leica DM 1000).

For phenotypic identification following biochemical tests were performed: Gram Test, oxidase, nitrate reduction, $\mathrm{H}_{2} \mathrm{~S}$ formation, citrate utilization, esculene hydrolysis, gelatin liquefaction, growth ability at $39^{\circ} \mathrm{C}$, fluorescent pigment production in King's B (under UV), sugars utilization ability and acid formation from glucose, sucrose, lactose, maltose, galactose, xylose, mannitol, sorbitol and levan formation from sucrose according to the methods of Jones \& Geider (2001).

\section{Results}

Above 40 samples - twigs, buds, flowers and fruitlets of the plants suspected on the fire blight disease were collected in the Mtskheta-Mtianeti and Shida Kartli Regions, Eastern Georgia in Spring of 2020. Based on visual observation and immunological test (Ea AgriStrip), 20 plant specimens were selected for further study.

Fig. 1 shows diseased plant samples collected in Mtskheta-Mtianeti and shida Kartli regions in which the pathogen E.amylovora was detected by the PCR (Bereswill et al., 1992) ( Fig.2).
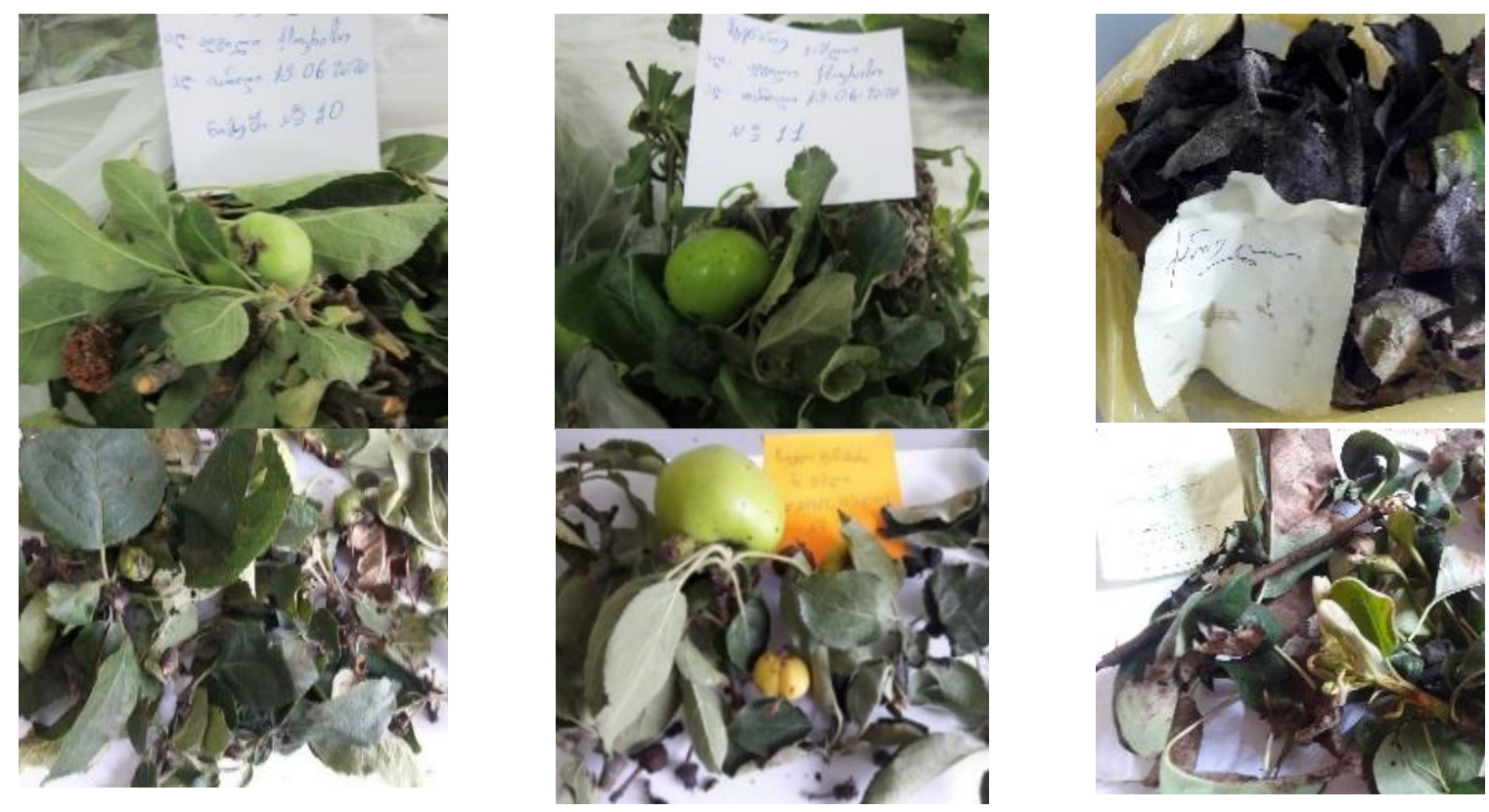

Fig.1. The fire blight diseased plant samples collected in Mtskheta-Mtianeti and shida Kartli regions in 2020.

1-2 Apple (Ksovrisi), 3 -apple (Kekhijvari), 4 - apple (Karaleti), 5 - apple (Tirdznisi), 6 pear (Osiauri).

Results of PCR-based detection of E.amylovora in symptomatic plant samples is represented on Fig.2. 

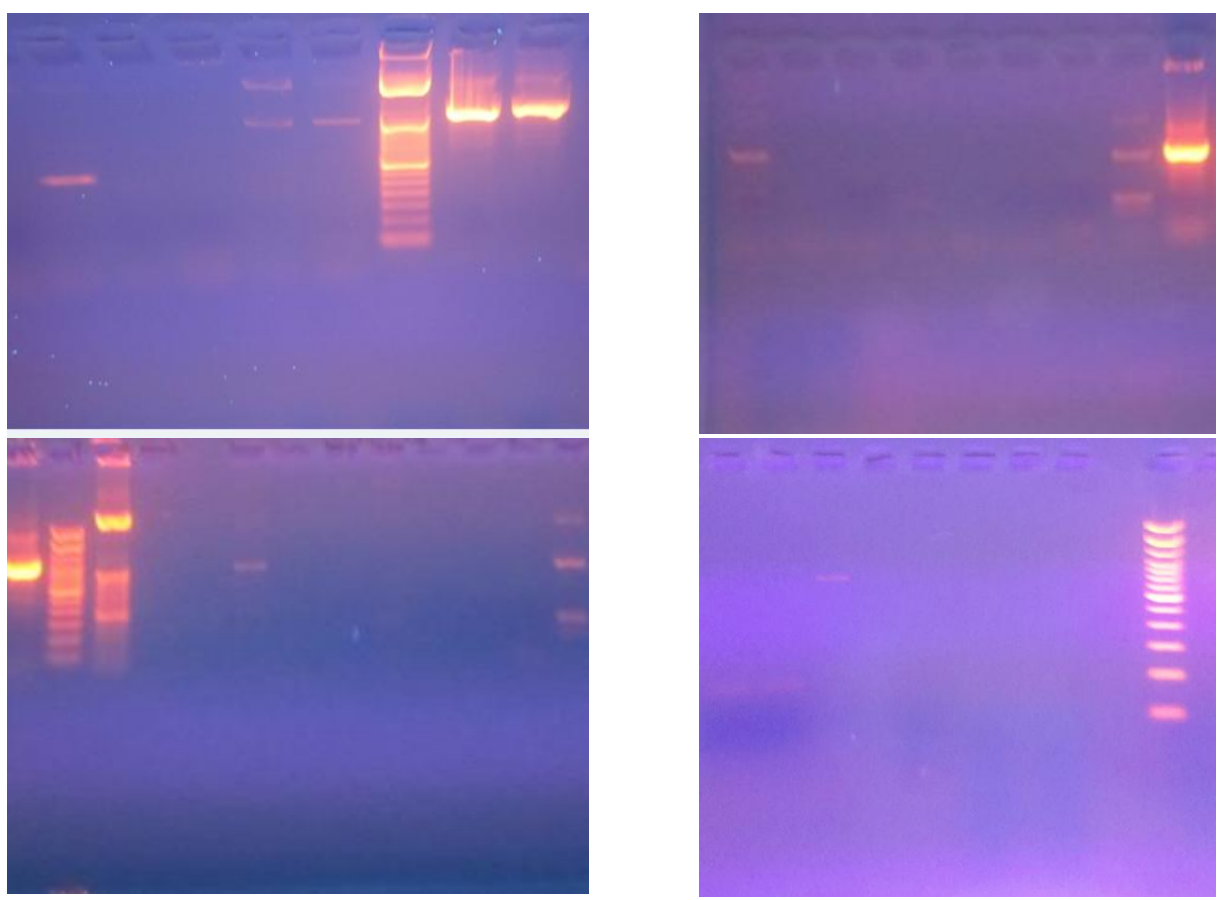

Fig. 2. Detection of fire blight causative pathogen in fire blight diseased plant samples electrophoregram of PCR fragments on 1.0\% agarose gel.

1- Quince (Mukhrani), quince (Ksovrisi), apple (Mukhrani), apple (Ksovrisi, samples \#10, 11), DNA ladder, PC NCPPB 683, Ref sample, NC;

2- Apple (Kekhijvari, sample \# 12), aplple (Tirdznisi), quince (Tirdznisi), apple (Karaleti), quince (Karaleti), apple (Pkhvenisi), NC, apple (Tirdznisi, sample \# 16), PC, DNA Ladder 100bp.

3- PC NCPPB 683, DNA 100bp, quince (Pkhvenisi), apple (Pkhvenisi), apple (Karaleti, sample \#14 dil.1:10), apple (Tirdznisi dil.1:10), quince (Tirdznisi dil. 1:10), quince (Karaleti dil. 1:10), apple (Pkhvenisi, dil. 1:10, quince (Karaleti), NC, apple (Tirdznisi, sample \#16, dil.1:10).

4- NC, pear (Osiauri, sample \#27), pear (Osiauri), quince (Osiauri), three samples apple Gomi, DNA ladder 100bp, pear (Gomi), PC NCPPB 683.

Synthesis of PCR amplicons with size of $900 \mathrm{bp}$ indicates on the existence of E.amylovora in 5 apple samples \#: 10,11,12, 14, 16, and one pear sample \#27 (Fig.2).

Colonies of some E. amylovora, isolated from the fire blight diseased samples, in which the pathogen was confirmed by PCR on different media ae shown on Fig.3.
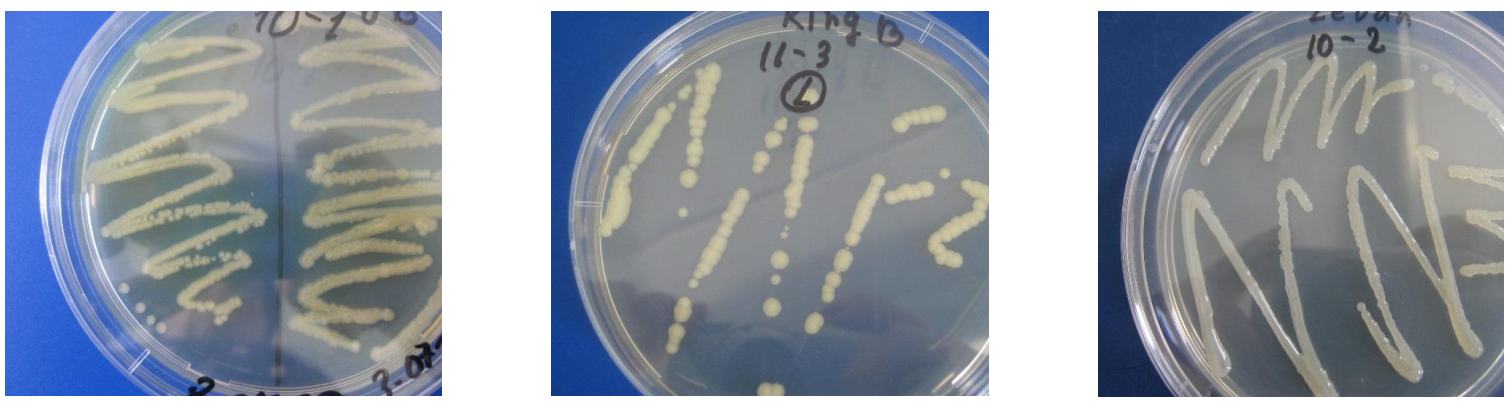

Fig. 3. E.amylovora colonies: \#1011 and 1133 on King's B medium; \#1012 on SNA) medium. 
One morphotype colonies were formed on CCT medium after $72 \mathrm{~h}$ - pale violet, circular, convex and mucoid, with slower growth than on King's B or SNA. Colonies on King's B appear after $24 \mathrm{~h}$ and are creamy white, circular.

The isolates \#\# 1012, 1022, 1023, 1131, 1133, 1212, 1612, 2763 and 2772, obtainmed from the 6 pathogen confirmed plant samples from different dilutions were confirmed to be E.amylovora by the PCR using primer pair G1 and G2.
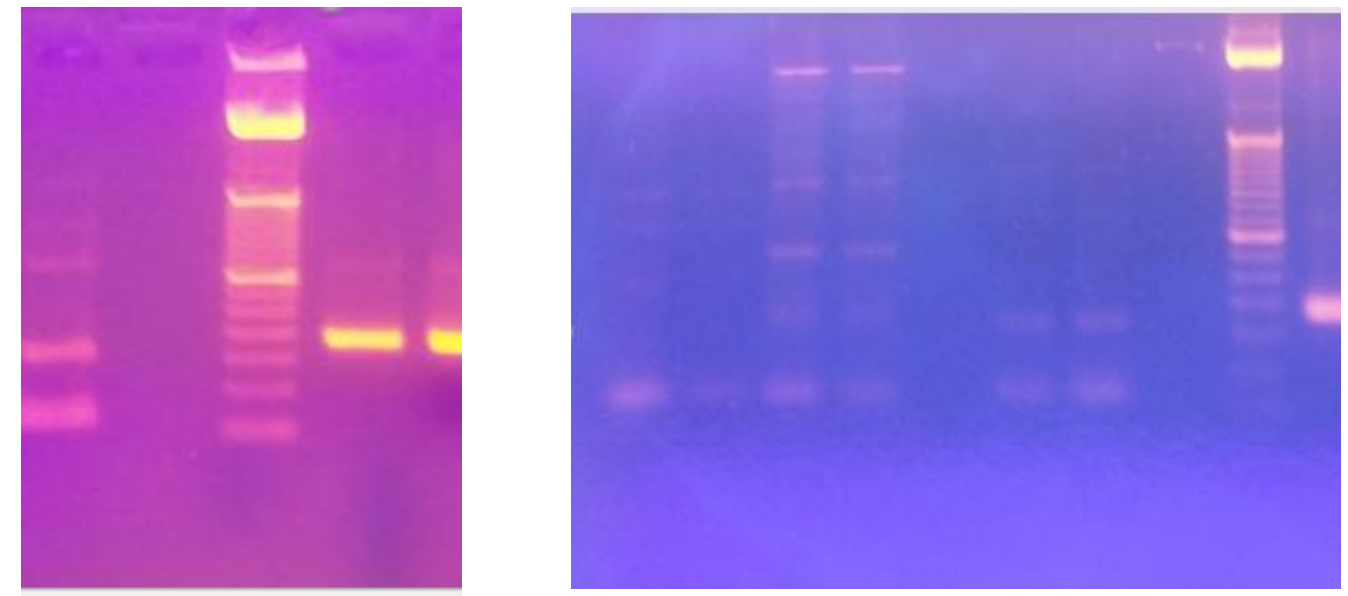

Fig. 4. Representative picture of E. amylovora molecular identification by PCR using G1 and G2 primer pair - electrophoregram of PCR fragments on 1.0\% agarose gel.

1 - Isolates from sample \#11: 1131, NC, 50bp DA ladder, 1133, PC NCPPB 683.

2 - Isolates from sample \#27: 2712, 2713, 2733, 2741, 2752, 2763, 2772, NC 50 bp DNA ladder, PC NCPPB 683.

Tests performed for the phenotypic analysis show that all isolates are Gram+ and are characterized by the abilities of the bacterial extracellular polysaccharide - levan formation on NSA medium, gelatin hydrolysis and citrate utilization. The isolates do not develop at $39^{\circ} \mathrm{C}$, are oxidase negative, are not able to nitrate reduction and $\mathrm{H}_{2} \mathrm{~S}$ formation.

Study of the physiological-biochemical properties of the E. amylovora Georgian isolates revealed a little difference in their sugars utilization ability. All isolates are characterized by acid formation from glucose, sucrose and galactose. Alternatively, none of them utilised lactose, maltose, xylose and mannitol. As about $25 \%$ of the isolates utilize sorbitol.

Thus, the above listed properties of the isolates indicate that they are Erwinia amylovora.

\section{Discussion}

The fire blight disease of fruit trees first appeared in village Ksovrisi, in the MtskhetaMtianeti region in 2016 (Gaganidze et al., 2018) and the local farmer relates it to imported apple seedling. Based and reffering on this publication EPPO publishes "2019/148 First report of Erwinia amylovora in Georgia (EPPO 2019). E.amylovora received the status of a limited-distribution quarantine pest in Georgia (Document is under preparation).

Since the forst discovery, the fire blight disease is spread in eastern and western Georgia, However, the number of cases is small (Gaganidze et al., 2021). In 2020 out of collected 40 samples in two regions of eastern Georgia - Mtskheta-Mtianeti and Shida Kartli Regions, 6 were confirmed to be diseased by the fire blight based on molecular detection of it's causative E. amylovora. In a total of 10 pure isolates were recovered from the disease confirmed samples serial dilutions. The presence of E. amylovora has been confirmed by specific PCR (Tailor et al., 2001) in the following isolates, \#\# 1012, 1022, 1023, 1131, 1133, 1212, 1412, 1612, 1742, and 2763.

Georgian Erwinia amylovora isolates according to biochemical and physiological properties are typical representatives of a very homogenous group of the species (Dye 1981; Holt et al. 1994; Paulin 2000). However, there are little differences among the isolates, expressed in the ability to 
utilize certain carbohydrates as carbon sources.

It is difficult to determine whether this disease was spread in Georgia by one or several imported seedling at the same time and whether it is due to further internal distribution. Study of the genetic diversity using modern molecular biology methods is planned to reveal the differences between the isolates. Sequence of the CRISPR regions (Rezzonico et al., 2011) of the four Georgian isolates revealed the presence of two distinct genotyps (Gaganidze et al., 2021). Extension of the genetic analysis to greater number of isolates is very important for epidemiological studies and to identify the pathogen type, source/sources and ways of distribution of the fire blight disease in Georgia.

Acknowledgements: this work is funded by the Shota Rustaveli National Science Foundation of Georgia (SRNSFG), grant number FR-19-22524.

\section{References:}

Beer SV, Norelli JL (1977) Fire Blight Epidemiology: Factors affecting release of Erwinia amylovora by ankers. Phytopathology 77, 9, 1119-125.

Bereswill S, Pahl A, Bellemann P, Zeller W, Geider K (1992) Sensitive and species-specific detection of Erwinia amylovora by polymerase chain reaction analysis. Applied and Environmental Microbiology 58: 3522-3526.

Billing E, Baker LA, Crosse JE, Garrett CM (1961) Characteristics of English isolats of Erwinia amylovora (Burrill) Winslow et al. J. Applied Bacteriol 24,195-2011.

Billing E (2000) Fire blight risk assesessment systems and models. In: Vanneste JL (ed) Fire Blight: The Disease and its Causative Agent Erwinia amylovora, CABI. Wallingford, UK, pp 293-318.

Dye DW (1981) A numerical taxonomic study of the genus Erwinia. New Zealand Journal of Agriculture Research 24, 223-229.

Gaganidze DL, Aznarashvili MA, Sadunishvili TA, Abashidze EO, Gureilidze MA, Gvritishvili ES (2018) Fire blight in Georgia. Annals of Agrarian Science 16, 1, 12-16. https://doi.org/10.1016/j.aasci.2018.02.001

Gaganidze D., Sadunishvili T., Aznarashvili M., Abashidze E., Gurielidze M., Carnal S., Rezzonico F., Zubadalashvili M. (2021) Fire blight distribution in Georgia and characterization of selected Erwinia amylovora isolates. Journal of Plant Pathology, 103 (Suppl 1), 121-129. https://doi.org/10.1007/s42161-020-00700-5

Holt, JG, Krieg NR, Sneath PHA, Staley JT, Williams ST (1994) Bergey's Manual of Determinative Bacteriology, 9th edn. Williams and Wilkins, Baltimore, Maryland, USA.

Ishimaru C, Klos EJ. (1984) New medium for detecting Erwinia amylovora and its use in epidemiological studies. Phytopathology 74, 1342-1345.

Jones AL, Geider K (2001) Gram-Negative Bacteria, Erwinia amylovora Group. In: Schaad NW, Jones JB, Chun W (eds.). Laboratory Guide for Identification of Plant Pathogenic Bacteria. 3rd Edn., APS Press, St Paul, MN, USA, pp 40-55.

King EO, Ward M, Raney DE (1954) Two simple media for thedemonstration of pyocyanin and fluorescein. Journal of Laboratory and Clinical Medicine 44, 301-307.

McGhee G, Sundin GW (2011) Evaluation of kasugamycin for fire blight management, effect on nontarget bacteria and assessement of kasugamycin resistance potential in Erwinia amylovora, Phytotpathology 101: 192-204

OEPP/EPPO Bulletin (2013), 43, 1, 21-45.

EPPO Reporting Service (2019/148): first detected in 2016 in Eastern and Western Georgia.

Paulin JP (1997) Fire Blight: Epidemiology and Control (1921-1996). Nachrichtenbl. Deut. Pllanzenschutzd., 49, $116-125$.

Paulin JP (2000) Erwinia amylovora: general characteristics, biochemistry and serology. In: Vanneste J (ed) Fire Blight, The Disease and its Causative Agent, Erwinia amylovora), CABI, Wallingford UK, pp 87-115.

Pulawska J, Sobiczewski P (2012) Phenotypic and genetic diversity of Erwinia amylovora: the causal agent of fire blight. Trees 26, 3-12.

Pusey PL (2002) Biological control agents for fire blight of apple compared under conditions limiting natural dispersal. Plant Dis 86, 639-644.

Rezzonico F, Smits THM, Duffy B (2011) Diversity and functionality of CRISPR regions in fire blight pathogen Erwinia amylovora. Appl Environ Microbiol 77, 3819-3829.

Sambrook J, Fitgah E, Maniatis T (2000) Molecular cloning: A Laboratory Manual, $3^{\text {rd }}$ ed. Cold spring, Harbor Laboratory.

Taylor RK, Guilford PJ, Clark RG, Hale CN, Forster RLS (2001) Detection of Erwinia amylovora in plant material using novel polymerase chain reaction (PCR) primers. New Zealand Journal of Crop and Horticultural Science 29, 3543.

Van der Zwet T (1996) Present worldwide distribution of fire blight. Acta Hortic 411, 7-8.

Van der Zwet T, Keil HL (1979) Fire blight-a bacterial disease of rosaceous plants. Agricultural Handbook 510, U.S. Department of Agriculture, Washington D. 


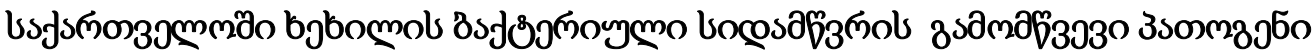

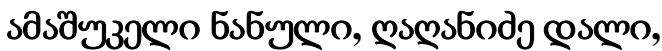

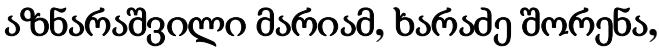

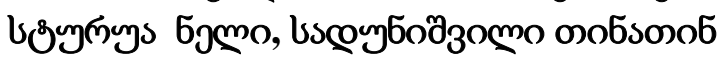

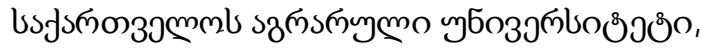

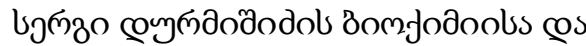

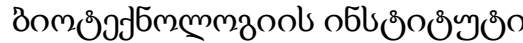

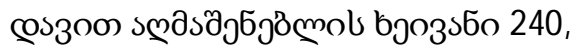

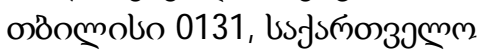

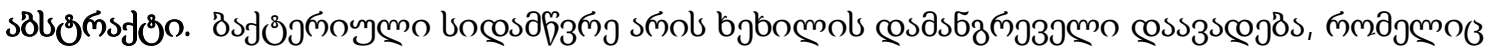

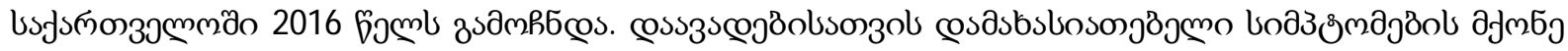

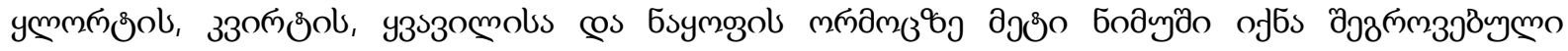

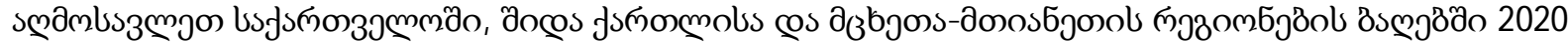

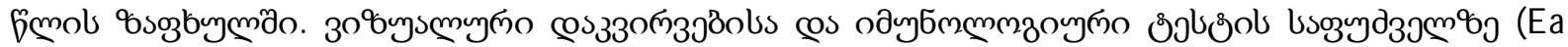

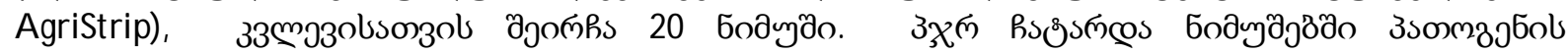
зsдmbs3m

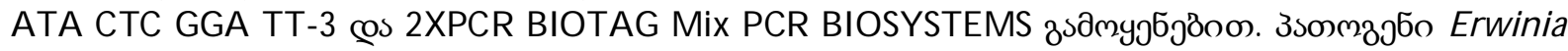

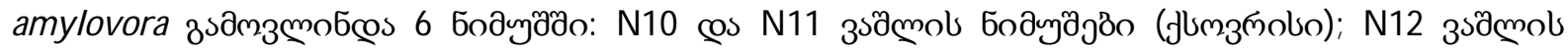

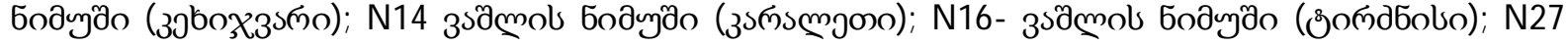

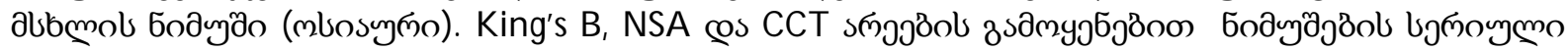

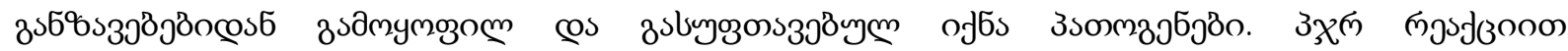

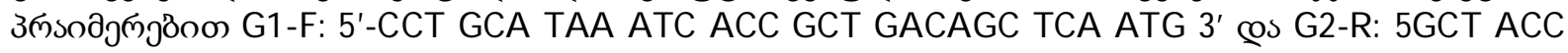

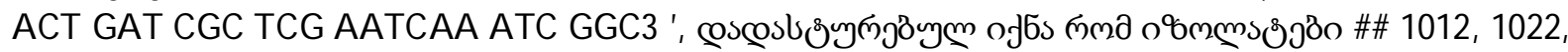
1023, 1131, 1133, 1212, 1412, 1612, 1742 @os 2763 snol Erwinia amylovora. E.amylovora jsmommo

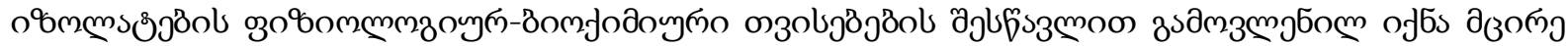

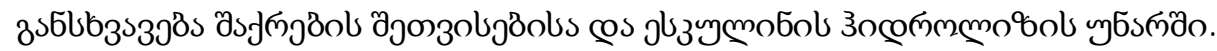

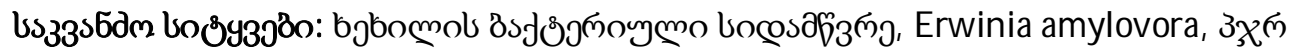

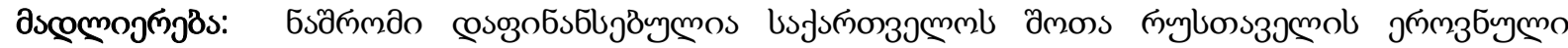

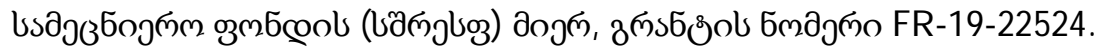

